\title{
Causes Of Corruption: Dynamic Panel Data Analysis Of Some Post Soviet Countries And East Asian Countries
}

Güzin Bayar, Middle East Technical University, Ankara/Turkiye

\begin{abstract}
Corruption is an important social and ethical problem. Determining root causes of it should be the first step to fight it. In this study, using a dynamic panel data approach, we try to determine the likely causes of level of corruption in some of the former USSR countries and East Asian countries. Regression results show that, past values of corruption and the level of political rights in a country are the factors that are most affecting the level of corruption in a country. Degree of opennes to the foreign trade, interference of government in the economy, FDI inflows, degree of civil liberties seem not to have significant effect on corruption level in a country. Level of inflation, unemployment, per capita GDP seems not to be among the causes of corruption, but rather they are "caused by the corruption". There seems no significant differences between East Asian Countries and post-communist countries in terms of corruption level, when the effect of other variables are kept constant.
\end{abstract}

Keywords: Corruption; dynamic panel; political rights

\section{INTRODUCTION}

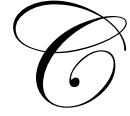

orrption is an important social and ethical problem. It is a type of economic crime that exist in nearly all societies to a greater or lesser extent. There are many definitions of corruption in the literature. World Bank define corruption as : "the abuse of public office for private gain." Shleifer and Vishny (1993) define corruption as "the sale by government officials of government property for personal gain." Although corruption is seen as a public sector problem, there can be corruption in private sector too. Usually there is a principal-agent relationship underlying corruption. A discretion is given through a contract by the principal to the agent, to behave in the name of the principal. If the agent, violating the contract, tries to get illegal benefit to the detriment of the principal, corruption occurs.

There is nearly a consensus in the literature about that corruption is harmful for a society, it discourages investments, distorts income distribution, causes inefficiencies and the waste of resources and harms democracy and ethics. There a few studies arguing that there may be some benefits of corruption (like Porta \& Vannucci (mentioned in Heywood, 1997), Leff (1964), Leys (1970), Lui (1985)) though. In these studies, the argument is that corruption can serve as an incentive payment speeding up bureaucracy, removing government imposed inefficient rules, giving opportunity to those most valuing the time to get permissions faster by paying for it. However, these studies misses a point; usually heavy bureacracy is created by the bureaucrats to be able to obtain more bribes.

On the otherhand, the literature on harmful effects of corruption is much wider. Many studies have shown that there is a negative relationship between corruption and investments and development level (Mauro (1995), Ahmad (2008), Le and Rishi (2006)). Mauro (1998) suggests that, political instability is greater in the countries where corruption is more widespread.

There may be many factors that facilitate corruption, encourage people to engage in corrupt activities. In the literature, wage level of public employees is shown to be one of the important factors determining corruption 
level. If wage level of the public employees are below the survival level of a family, many employees think of closing the gap with corruption. High wages makes losing the job more undesirable so decreases corruption. As economy opens to foreign trade and the level of national income rises, corruption level is expected to decrease. In an open and rich country there are less presssure on redistribution. In low income countries people fight to share a constant perceived pie; as development level increases, production and productivity gets more important, hard work gets more valuation. Existence of rule of law, political freedoms, free media and democracy are important factors decreasing corruption. In non-democratic countries ruling class usually corrupts and since there is no free media to announce it or no opposition to question it, corruption gets more widespread. As education level of the people increase, level of corruption is expected to decrease. High inflation and high level of public expenditures are expected to rise corruption in a country by increasing rent seeking culture in the country. Quality of bureaucratic services and the justice system are also very important factors affecting the level of corruption in a country. Level of unemployment have ambiguous effect on corruption. On the one hand increasing unemployment may increase rent seeking behavior thus rises corruption; on the otherhand, high unemployment makes public officers more afraid of losing their jobs so decreases corruption.

There are many empirical studies on the causes of corruption in the literature. Treisman (2000) using panel data of developed and developing countries, shows that the countries that are more developed and more open to foreign trade have less corruption. Although current leel of democracy in a country is an significant factor affecting corruption, the countries who have a long history of democracy and rule of law have significantly lower levels of corruption.

Pelligrini and Gerlah (2008), examining cross sectional data of 107 countries, reach to the same conclusion with Treisman (2000) about the affect of democracy tradition on decreasing corruption. Pelligrini and Gerlah (2008) also find that political instability increases corruption and prevalance of the newspapers decreases it (by informing the people about corruption cases and thus serving as a way of discouragement for corrupt people). There is not a statistically significant relationship between the government intervention the economy and the corruption.

Rijckeghem and Weder (2001) examining panel data of 31 countries between 1982-94, find a statitstically significant negative relationship in the long term between corruption and the ratio of public sector emploees' wage level to the wage level of the employees in the private productive sectors. On the other hand, authors can not find a relationship between neither education and corruption nor gross domestic product per capita and corruption.

Chand and Moene (1997), examine Gana Public Expenditure reform and show that the bonus program established for tax officals, increase in penalties and decrease in the general tax level caused much improvement in the ability of Gana government ot collect taxes.

On the otherhand, Buscaglia (2001), for some Latin American countries, finds that there is no statistically significant relationship between wage levels of judges and corruption in the justice system.

Tosun (2003), using data of 44 countries for the 1982-1995 finds that rule of law, quality of bureaucracy and (against expectations) public expenditures have decreasing effect on corruption. Level of inflation, national income growth, wage level of public employees seems not to have a statistically significant effect on corruption.

Zakaria (2009) finds for Pakistan that openness to foreign trade decreases corruption. Moreover, corruption decreases with increasing education level, national income, political freedom and the decreasing level of government intervention in the economy.

Broadman and Recanatini (2000) in their article examining 26 transition countries, show that greater market entry barriers, a less effective legal system, less competitive infrastructure services are associated with higher corruption. Increasing democracy has a decreasing effect on corruption while coefficient of the openness variable, is not statisticaly significant. The coefficients of GDP per capita is insignificant.

Rauch and Evans (2000) collect survey data on various elements of bureaucratic structure for 35 countries. As a result of the regression analysis, authors found that per capita GDP is a significant determinant of corruption 
and meritocratic recruitment and education each are significant in explaining one of the corruption measures. All three has decreasing effect on corruption. On the otherhand, the coefficients of career, salary and ethnic diversity measures are insignificant for both corruption measures.

Goldsmith (1999), using a sample of 34 low and middle income countries, show that, per capita GNP has a strongly significant decreasing effect on corruption variable; increasing economic liberalization and increasing centralization of the state are also significant factors decreasing corruption. Although less significant than other variables, higher levels of political democratization is also associated with diminished corruption.

Lee (1981) (mentioned in Berkman (1988)) examines the relationship between traditional values and tolerance for corruption and finds that those of the surveyed people whose traditionality points are higher tolerate corruption more and those with lower traditional bonds, tolerate corruption less. Results also show that, those who are comparatively older and less educated are more tolerant to corruption in comparison to the ones who are younger and more educated.

In the article by Ades and Di Tella (1997) a number of panel and cross-section regressions analysis are done and results in general show that more active industrial policy of government is significantly correlated with higher levels of corruption. Degree of political rights in the country has no significant effect on corruption and education level. Degree of openness to foreign trade and security level of the country have significantly negative relationships with the level of corruption.

Laffont and Guesson (1999) empirically test the relationships between competitiveness and corruption on African data. Results of the regression show that openness variable (imports/GDP, which is assumed to show competitiveness) is a strongly significant factor decreasing corruption. Growth rate increase also decreases corruption. Foreign aid and illiteracy rate has a weakly significant increasing effect on corruption. When an interaction variable between the competition and corruption variables is introduced, it is shown that coefficient of the openness variable (imports (GDP)) is positive for high levels of corruption but negative for low-levels of it.

Goel and Rich (1989), using US data, show that, probability of being convicted and severity of punishment are decreasing corruption. The policing variable has no significant effect. Raising salaries of public employees have decreasing effect on the level of corruption. Coefficient of unemployment variable is positive and significant, which may reflect a rise in bribe offers during recessions. Lastly, advertising variable is significant and positive, most probably due to the fact that an increase in the volume of advertising leads to greater corruption by raising individual rates of discount of future.

Identifying root causes of a problem is the first important step towards sloving it. Aim of this study is, using a dynamic panel data approach, to estimate the factors that leads to corruption and determine relative importance of each in explaining the level of corruption in the countries studied. We make a comparison between some Post-Comminist countries and some East Asian countries in this respect. In the second part of the article data and analysis is explained. In the third part, regression results are printed and interpreted. In the fourth part, concluding remarks takes place.

\section{DATA AND METHODOLOGY}

Data set consists of the 3 countries that have been established after the collapse of the Soviet Union: Russian Federation, Kazakhistan, Ukraine, and newly developing countries of East Asia (in fact some of them are now within the classification of "developed countries"): China, India, Indonesia, Malaysia, Singapore, South Korea, Taiwan. Countries are selected according to data availability. Dynamic panel data analysis of these countries between 1999-2009 were done.

Independent variable of the regresssion is the level of perceived corruption in these countries.

In fact, exact measures of corruption are difficult to find. It has numerous types and is unobservable. So, corruption is measured by proxies. 
World Bank defines four types of proxies to measure corruption: i) Net Asset Evaluation ii) Arrests and convictions iii) Survey methodology iv) Macroeconomic empirical studies.

Berg (2001) classifies corruption measures into two: objective measures and subjective measures. Objective measures are quantifications based on verifiable information, most often used of which are number of corruption charges or the number of internet search engine hits on corruption in a particular country. Subjective measures are perception or experience based and composed of data collected from surveys or polls in which individuals are asked to assess the level of corruption.

Most frequently used measures in both cross-country comparisons and empirical research are survey measures provided by various international institutions or private researchers.

Institutions like Economic Intelligence Unit, Political Risk Services Inc., Political \& Economic Risk Consultancy, Institute for Management Development, World Bank, Price Waterhouse Coopers, Word Economic Forum, Freedom House, Transparency International provide surveys on corruption perception for a number of countries.

A number of economists like Hall and Yogo, Kaufmann, Kraay and Ziodo-Laboton, Ades \& Di Tella (mentioned in Jain, 2001), Helpman, Jones, Kaufmann \& Schankerman, Neumann (mentioned in Berg (2001)) also provide perceptions based or experience based indicators of corruption for the countries investigated.

In this study as dependent variable we use "Corruption Perceptions Index (CPI)" of Transparency International (TI) as a proxy for corruption. CPI since 1995, ranks more than 180 countries in terms of their perceived level of corruption. While ranking, TI use 13 different opinion surveys done in these countries and expert assesments. An index is established based on survey results. Index varies betwen 0-10, 0 means that country is perceived to be highly corrupt, 10 means that country is perceived to have low levels of corruption. CPI is one of the most used corruption measure in the literature on corruption.

As mentioned in many theoretical and empirical studies on corruption, degree of political rights and civil liberties in a country are important determinants of corruption. As political rights and civil liberties increase, corruption level is expected to decline. However, objective measures of such pllitical and social variables are difficult to obtain. Jain (2001) gives a list of proxies for these variables and the researchers providing data. In this study, political rights and civil liberties data published by "Freedom House" are used as proxies for these independent varibles. Freedom House rank countries in terms of their "freedom" measures since 1972. Freedom House asseses the state of freedom, political rights and civil liberties in 195 countries and 14 related and disputed territories and publishes yearly. Surveys are done and then processed by a team of regional experts and scholars. An index is established based on survey results. Numerical rating varies between 1-7; a rating of 1 indicating the highest degree of freedom and 7 the lowest level of freedom. Freedom House defines political rights and civil liberties as:

Political rights enable people to participate freely in the political process, including the right to vote freely for distinct alternatives in legitimate elections, compete for public office, join political parties and organizations, and elect representatives who have a decisive impact on public policies and are accountable to the electorate. Civil liberties allow for the freedoms of expression and belief, associational and organizational rights, rule of law, and personal autonomy without interference from the state (Freedom House, 2010).

"Political rights" and "civil liberties" are two of the independent variables in the regression. Other independent variables are mostly macroeconomic aggregates : per capita gross domestic product (purchasing power parity adjusted) (variable name PCGDPPP), unemployment rate (variable name UNEMP), exports share in GDP (variable name: EXPORT), government budget expenditures as a share of GDP (varibale name BUDGET), consumer price inflation (variable name INFLA), inward FDI flow as a percentage of total fixed investments in the country (variable name : FDI) and to represent education level tertiatry education gross enrollment rate (variable name : EDUCATION) are taken. All variables except education variable were taken from Economist Intelligence Unit. Education variable were obtained from Worl Bank database. To be able to observe whether there are significant differences between former USSR countries and East Asian Countries, we defined USSR dummy, which 
takes value of zero for East Asian Countries (expect China, since it is a country which has much similarities with former USSR countries in terms of former regime and regime change) and value of one for the former communist countries (variable name : USSRDum).

To test stationarity of the variables in panel data, there are many tests offerred by various economists in the literature. Levin and Lin (1992, 1993), Im, Pesaran and Shin (1997), Maddala and Wu (1999),Kao (1999) and Quah (1994), Kao and Chiang (1998), Pedroni (1995, 1997), McCoskey and Kao (1998), Phillips and Moon (1999) are among these.

In this regression, Im, Pesaran and Shin W-Statistic, ADF-Fisher Chi-Square and PP-Fisher Chi-Square tests are preferred. Because these tests assumes that unit root process are not the same between cross sectional units; which is a more suitable assumption regarding that our data is composed of countries with very divergent characteristics. Moreover, these tests have better small sample properties than the others (for a review see Coşar (2002)).

Regression is estimated using panel generalized method of moments. Cointegration between the variables are tested using residuals stationarity based tests.

\section{RESULTS AND INTERPRETATION}

Unit root tests of all varibles are done for 3 different test methodology. When the test results do not agree on the rejection/non-rejection of null hypothesis, that of PP-Fisher Chi-Square test result is taken. Null hypothses is the existence of unit root. Results for the variables are given below:

\begin{tabular}{|c|c|c|c|c|c|c|}
\hline \multirow[b]{2}{*}{ Variable } & \multicolumn{2}{|c|}{ Im, Pesaran and Shin W-stat } & \multicolumn{2}{|c|}{ ADF - Fisher Chi-square } & \multicolumn{2}{|c|}{ PP - Fisher Chi-square } \\
\hline & Statistic & Probability & Statistic & Probability & Statistic & Probability \\
\hline Corruption & -0.7142 & 0.2376 & 28.0319 & 0.1086 & 25.0085 & 0.2011 \\
\hline $\mathrm{d}($ Corruption) & -2.1101 & 0.0174 & 36.9817 & 0.0118 & 86.8677 & 0.0000 \\
\hline Civillib & 0.2493 & 0.5984 & 6.7115 & 0.7524 & 6.3895 & 0.7815 \\
\hline $\mathrm{d}($ Civillib) & -0.5396 & 0.2947 & 11.4429 & 0.3241 & 19.6388 & 0.0329 \\
\hline $\mathrm{d}^{2}$ (Civillib) & -2.5022 & 0.0062 & 25.6930 & 0.0042 & 35.3017 & 0.0001 \\
\hline Budget & -0.4721 & 0.3184 & 33.6964 & 0.0283 & 13.0395 & 0.8757 \\
\hline d(Budget) & -2.0454 & 0.0204 & 37.9452 & 0.0090 & 70.1217 & 0.0000 \\
\hline Education & 0.7185 & 0.7638 & 17.3676 & 0.3622 & 19.9719 & 0.2215 \\
\hline $\mathrm{d}$ (Education) & -0.2404 & 0.4050 & 18.5530 & 0.1827 & 26.2476 & 0.0506 \\
\hline $\mathrm{d}^{2}$ (Education) & -0.9639 & 0.1676 & 21.7925 & 0.0830 & 28.8164 & 0.0252 \\
\hline Export & 3.1825 & 0.9993 & 10.3302 & 0.9618 & 6.1109 & 0.9987 \\
\hline d(Export) & 0.4045 & 0.6571 & 15.7682 & 0.7309 & 31.6102 & 0.0476 \\
\hline $\mathrm{d}^{2}$ (Export) & 0.2292 & 0.5906 & 26.8529 & 0.1395 & 53.3104 & 0.0001 \\
\hline FDI & -0.5403 & 0.2945 & 21.3948 & 0.3742 & 24.5511 & 0.2191 \\
\hline $\mathrm{d}(\mathrm{FDI})$ & -1.8211 & 0.0343 & 33.1979 & 0.0321 & 66.7865 & 0.0000 \\
\hline Infla & -1.6069 & 0.0540 & 36.0563 & 0.0151 & 86.3196 & 0.0000 \\
\hline PCGDPPP & 1.1894 & 0.8828 & 12.8341 & 0.8844 & 3.5040 & 1.0000 \\
\hline d(PCGDPPP) & -0.0063 & 0.4975 & 15.5695 & 0.7429 & 32.4093 & 0.0391 \\
\hline $\mathrm{d}^{2}$ (PCGDPPP) & 2.4004 & 0.9918 & 4.7923 & 0.9998 & 32.7517 & 0.0359 \\
\hline Polright & 0.5350 & 0.7037 & 7.3525 & 0.8335 & 15.0427 & 0.2391 \\
\hline $\mathrm{d}($ Polright $)$ & -1.5254 & 0.0636 & 20.7146 & 0.0547 & 61.5788 & 0.0000 \\
\hline Unemp & -2.9312 & 0.0017 & 43.4678 & 0.0018 & 63.4343 & 0.0000 \\
\hline
\end{tabular}

Test results suggest that, corruption, civil liberties, political rights, share of government expenditures in GDP, tertiary school gross enrollment rate, share of exports in GDP, inward FDI inflows, GDP per capita (purchasing power parity adjusted) variables are integrated to order one, so we used them in first differences. On the other hand, inflation and unemployment variables are stationary at their levels according to all three statistics. So we use that two variables in the equation without taking their differences. 
Since we use stationary variables in the regresssion (either stationary at levels or made stationary by taking first differences), we do not need to make panel co-integration tests. Regression results would not be spurious. The regression we estimate is represented as :

$$
\begin{aligned}
& \Delta(\text { Corruption })=\beta_{0}+\beta_{1} \Delta(\text { Corruption }(-1))+\beta_{2} \Delta(\text { Civillib })+\beta_{3} \Delta(\text { FDI })+\beta_{4} \Delta(\text { Polright }) \\
& +\beta_{5} \Delta(\text { PCGDPPP })+\beta_{6} \text { USSRDum }+\beta_{7} \text { Infla }+\beta_{8} \text { Unemp }+\beta_{9} \Delta(\text { Budget })+\beta_{10} \Delta(\text { Export })
\end{aligned}
$$

In all regressions education variable has a coefficient not statistically different from zero. Moreover, for some countries, for some years, education data is not available; thus including this data makes our panel unbalanced. So, we exclude this variable from the regresssion. Initial regression results are printed below:

Table 1 : Initial Regression Results

Dependent Variable: D(CORRUPTION)

Method: Panel Generalized Method of Moments

Sample (adjusted): 20022009

Cross-sections included: 10

Total panel (balanced) observations: 80

Cross-section weights instrument weighting matrix

Instrument list: D(CORRUPTION (-2)) D(CIVILLIB) D(FDI)

D(POLRIGHT) D(PCGDPPP) USSRDUM INFLA UNEMP

\begin{tabular}{|c|c|c|c|c|}
\hline Variable & Coefficient & Std. Error & t-Statistic & Prob. \\
\hline D(CORRUPTION(-1)) & 0.947851 & 0.593827 & 1.596173 & 0.1150 \\
\hline D(CIVILLIB) & -0.101944 & 0.103044 & -0.989322 & 0.3260 \\
\hline $\mathrm{D}(\mathrm{FDI})$ & -0.003335 & 0.002891 & -1.153801 & 0.2526 \\
\hline D(POLRIGHT) & -0.211672 & 0.127903 & -1.654949 & 0.1025 \\
\hline $\mathrm{D}$ (PCGDPPP) & $2.63 \mathrm{E}-05$ & $4.32 \mathrm{E}-05$ & 0.608273 & 0.5450 \\
\hline USSRDUM & -0.024795 & 0.077189 & -0.321221 & 0.7490 \\
\hline INFLA & -0.001414 & 0.006134 & -0.230514 & 0.8184 \\
\hline UNEMP & 0.010370 & 0.014468 & 0.716771 & 0.4759 \\
\hline D(BUDGET) & 0.032779 & 0.027603 & 1.187524 & 0.2391 \\
\hline D(EXPORT) & 0.000318 & 0.000488 & 0.651773 & 0.5167 \\
\hline $\mathrm{C}$ & -0.126865 & 0.133671 & -0.949080 & 0.3459 \\
\hline R-squared & -0.650284 & \multicolumn{2}{|l|}{ Mean dependent var } & 0.027500 \\
\hline Adjusted R-squared & -0.889455 & \multicolumn{2}{|l|}{ S.D. dependent var } & 0.219306 \\
\hline S.E. of regression & 0.301452 & \multicolumn{2}{|l|}{ Sum squared resid } & 6.270252 \\
\hline Durbin-Watson stat & 2.815621 & \multirow{2}{*}{\multicolumn{2}{|c|}{ J-statistic }} & $8.40 \mathrm{E}-28$ \\
\hline Instrument rank & 11.00000 & & & \\
\hline
\end{tabular}
D(BUDGET) D(EXPORT) C

We estimated the equation using panel generalized method of moments. Since the lagged values of the dependent variable is correlated with error terms, instrumental variables must be used to get unbiased coefficient estimates. Independent variables except lagged values of the dependent variables served as instruments of themselves and two period lagged values of the dependent variable served as instrument of one period lagged values of dependent variable; that is $\mathrm{AR}(1)$ term in the regresssion.

To check whether there are any feedback effects from the dependent variable to independent variables, we have done granger causality tests and we have seen that, except for the unemployment and inflation variables, in non of the variables, there is a causation running from corruption to the independent variables at the $\% 5$ significance level. Feedback effect is also significant at \%5,7 level for GDP per capita variable. That is, it seems that, corruption is one of the factors affecting level of GDP per capita, inflation and unemployment in a country. 
Table 2: Granger Causality Test Results

\begin{tabular}{|l|c|c|c|}
\hline \multicolumn{1}{|c|}{ Null Hypothesis: } & Obs & F-Statistic & Probability \\
\hline INFLA does not Granger Cause CORRUPTION & 90 & 0.14887 & 0.86190 \\
\hline CORRUPTION does not Granger Cause INFLA & & 3.87512 & 0.02451 \\
\hline \multicolumn{2}{|l|}{} & & \\
\hline PCGDPPP does not Granger Cause CORRUPTION & 90 & 0.08267 & 0.92073 \\
\hline CORRUPTION does not Granger Cause PCGDPPP & 2.95684 & 0.05735 \\
\hline \multicolumn{2}{|l|}{} & 90 & 0.14914 \\
\hline UNEMP does not Granger Cause CORRUPTION & & 4.43725 & 0.86168 \\
\hline CORRUPTION does not Granger Cause UNEMP & & 0.01469 \\
\hline
\end{tabular}

Granger causality test show no indication of the causation from either unemployment, inflation or per capita GDP to corruption. Moreover, coefficients of all three variables are not significant in our initial regression and due to feed back effects, they are correlated with the error term and thus makes the coeffient estimates biased. So we remove them from the regression. When we remove these variables, all of the other variables are integrated to order one, thus, we can use theirs levels instead of differences and test whether there is a cointegration between them. For the lagged values of the dependent variable we use two period lagged values as instruments and the other independent variables serve as instruments of themselves.

Table 3 : The Second Regression Results

Dependent Variable: CORRUPTION

Method: Panel Generalized Method of Moments

Sample (adjusted): 20002009

Cross-sections included: 10

Total panel (balanced) observations: 100

Cross-section weights instrument weighting matrix

Instrument list: CORRUPTION (-2) CIVILLIB FDI POLRIGHT

\begin{tabular}{|l|c|c|c|c|}
\hline \multicolumn{1}{|c|}{ Variable } & Coefficient & Std. Error & t-Statistic & Prob. \\
\hline CORRUPTION(-1) & 1.037398 & 0.025142 & 41.26108 & 0.0000 \\
\hline CIVILLIB & 0.095950 & 0.061041 & 1.571898 & 0.1194 \\
\hline FDI & -0.001068 & 0.002179 & -0.490091 & 0.6252 \\
\hline POLRIGHT & -0.113353 & 0.057982 & -1.954984 & 0.0536 \\
\hline USSRDUM & 0.196161 & 0.143467 & 1.367295 & 0.1749 \\
\hline BUDGET & -0.002297 & 0.006115 & -0.375569 & 0.7081 \\
\hline EXPORT & $1.89 \mathrm{E}-05$ & 0.000116 & 0.162456 & 0.8713 \\
\hline C & -0.055642 & 0.179861 & -0.309360 & 0.7577 \\
\hline R-squared & 0.984879 & Mean dependent var & & 2.057000 \\
\hline Adjusted R-squared & 0.983729 & S.D. dependent var & & 6.141851 \\
\hline S.E. of regression & 0.273214 & Sum squared resid & & $4.31 \mathrm{E}-21$ \\
\hline Durbin-Watson stat & 2.096985 & J-statistic & & \\
\hline Instrument rank & 8.000000 & \multicolumn{3}{|l}{} \\
\hline
\end{tabular}

From the regression results, it is seen that, degree of opennes to the foreign trade (measured by the share of exports in GDP), presence of government in the economy (measured by the share of government budget expenditures in GDP), inward FDI flows as a share of GDP, degree of civil liberties are factors that do not have significant effect on corruption level in a country. Dummy variable also has an insignificant coefficient, showing that there are no significant differences between East Asian Countries and post-communist countries in terms of corruption, when the effect of other variables are kept constant. Insignificance of the coefficient of the dummy variable does not change when we define dummy as taking value of one only for 3 former USSR countries.

From the regresssion results, seems that, the only significant factors (at \%5 significance level) that can affect corruption are the past values of corruption and the level of political rights in a country. Corruption shows path dependence, past year's value of it is one of the most powerful determinants of the level of today's corruption. 
In line with the expectations, as the situation of the political rights worsens in a country, corruption level rises (remember, the rise of value of corruption index means less corruption and the decline of value of political rights index means more rights). Residuals of the regression are stationary according to Im, Pesaran and Shin WStatistic, ADF-Fisher Chi-Square and PP-Fisher Chi-Square unit root tests, so we can say that, there is cointegration between the variables. Test results are given below:

Table 4 : Unit Root Tests of the Residuals

\begin{tabular}{|c|c|c|c|c|c|c|}
\hline & \multicolumn{2}{|c|}{ Im, Pesaran and Shin W-stat } & \multicolumn{2}{|c|}{ ADF - Fisher Chi-square } & \multicolumn{2}{|c|}{ PP - Fisher Chi-square } \\
\hline & Statistic & Probability & Statistic & Probability & Statistic & Probability \\
\hline Residuals & -2.474 & 0.016 & 37.539 & 0.010 & 95.796 & 0.000 \\
\hline
\end{tabular}

There is an opinion in the literature that, the cointegration tests based on the stationarity of the residuals are biased towards accepting the existence of cointegration. Pedroni $(1995,1997)$ shows that problems like lack of exogeneity of the regressors and the dependency of the residuals on the distribution of the estimated coefficients causes biases in the cointegration tests based on testing the stationarity of the residuals. However, as we have shown above, our regression do not have these properties; thus we can trust the unit root tests of the residuals to comment on cointegration.

\section{CONCLUDING REMARKS}

Corruption is an important social and ethical problem. Determining root causes of it should be the first step to be able to fight it. There is a large literature on the causes of corruption.

Wage level of public employees, level of national income, degree of openness to foreign trade, existence of rule of law, political freedoms, free media and democracy, education level of the people, inflation, quality of bureaucratic services and the justice system, level of unemployment are some of the factors that are shown to affect corruption in some way or another.

In this study, using a dynamic panel data approach, we try to determine the likely causes of level of corruption in some of the former USSR countries and East Asian countries. Regression results show that, past values of corruption and the level of political rights in a country are the factors that are most affecting the level of corruption in a country. Degree of opennes to the foreign trade, interference of government in the economy, FDI inflows, degree of civil liberties seem not to have significant effect on corruption level in a country. Level of inflation, unemployment, per capita GDP seems not among the causes of corruption, but rather they are "caused by the corruption". There seems no significant differences between East Asian Countries and post-communist countries in terms of corruption, when the effect of other variables are kept constant.

\section{AUTHOR INFORMATION}

Dr. Güzin Bayar graduated from Ph. D program of Middle East Technical University (Ankara, Turkey) Faculty of Economic and Administrative Sciences Department of Economics in 2003. Between Fall 2004-Fall and 2006 she lectured ECON-443- Game Theory and Its Applications in Middle East Technical University Department of Economics (An elective course open to senior undergraduate students and graduate students). Between April 2007June 2010 she worked as Commercial Counselor of Turkish Embassy in Minsk/Belarus.

Publications in the Journals Listed in Social Sciences Citation Index:

Bayar, G. (2005), "The Role of Intermediaries in Corrupt Transactions", Public Choice, 122(3), 277-298.

Bayar, G. (2002), "Effects of Foreign Trade Liberalization on the Productivity of Industrial Sectors in Turkey", Emerging Markets Finance and Trade, 38(5), pp. 46-71.

Publications in the Journals Listed in Econ Lit:

Bayar, G. (2009), "Corruption and intermediaries - A game theoretical approach", METU Studies in Development, $36(1)$, pp. 25-49. 
Bayar, G. (2009), "Business Cycles and Foreign Trade in the Turkish Economy", Middle Eastern Finance and Economics, 3, pp. 39-48.

Bayar, G., Çalışkan, O. (2007), "Türkiye-AB İlişkileri: Bir Oyun Teorisi Yaklaşımı” (Turkey-EC Relationships: A Game Theoretical Approach), METU Studies in Development, 34(1), pp. 16-62.

\section{REFERENCES}

1. Ades, A. and Di Tella, R. (1997). National Champions and Corruption: Some Unpleasant Interventionist Arichmetic. The Economic Journal, 107, 1023-1042.

2. Ahmad, N. (2008). Corrupt Clubs and the Convergence Hypothesis, Journal of Economic Policy Reform, 11(1), 21-28.

3. Bardhan, P. (1997). Corruption and Development: A Review of Issues. Journal of Economic Literature, 35, 1320-1346. pp. 1320-1346.

4. Bardhan, P. (1997). Corruption and Development: A Review of Issues. Journal of Economic Literature, 35, 1320-1346.

5. Berkman, Ü.A. (1988). Yolsuzluk ve Rüşvete Karşı Önlemler. Journal of Economics and Administrative Studies, 2(1), 39-56.

6. Berg, E. (2001). How Should Corruption be Measured?. London School of Economics and Political Science MSc Economics Extended Essay

7. Broadman, G.H. and Recanatini, F. (2000). Seeds of Corruption: Do Market Institutions Matter?. The World Bank Europe and Central Asia Regional Operations Poverty Reduction and Economic Management Department.

8. Broadman, G.H. and Recanatini, F. (2000). Seeds of Corruption: Do Market Institutions Matter?. The World Bank Europe and Central Asia Regional Operations Poverty Reduction and Economic Management Department.

9. Chand, S.K. and Moene, K.O. (1997). Controlling Fiscal Corruption. IMF Working Papers, WP/97/100.

10. Coşar, E. E., (2002). "Price and Income Elasticities of Turkish Export Demand : A Panel Data Apllication", Central Bank Review, 2, 19-53.

11. Freedom House (2010). http://www.freedomhouse.org (reached: 24/09/2010).

12. Goel, K.R. and Rich, D.P. (1989). On the Economic Incentives for Taking Bribes. Public Choice, 61(3), 269-75. ss.

13. Goldsmith, A.A. (1999). Slapping the Grasping Hand: Correlates of Political Corruption in Emerging Markets. American Journal of Economics and Sociology, 58(4), 865-883. ss.

14. Heywood, P. (1997), "Political Corruption: Problems and Perspectives", Political Studies, 45(3), 417-435.

15. Im, K. S., Pesaran, M. H., and Shin, Y., (1997). Testing for Unit Roots in Heterogeneous Panels, University of Cambridge, Deparment of Applied Economics.

16. Kao, C., 1999. Spurious Regression and Residual Based Tests for Cointegration in Panel Data", Journal of Econometrics, 90:1-44.

17. Kao, C., and Chiang, M., 1999. On the Estimation and Inference of a Cointegrated Regression in Panel Data, Working Paper, Center for Policy Research, Syracuse University, New York.

18. Le, Q. V. ve Rishi, M. (2006). Corruption and Capital Flight: An Empirical Assessment, International Economic Journal, 20(4), 523-540.

19. Leff N. H. (1964), "Economic Devleopment Through Bureaucratic Corruption”, In A. J. Heidenheimer (ed.), Political Corruption: Readings in Comparative Analysis, pp. 8-14. New York: Holt Reinehart.

20. Levin, A., and Lin, C. F., (1992). Unit Root Tests in Panel Data: Asymptotic and Finite Sample Properties, University of California, San Diego, Discussion Paper No: 92-93.

21. __ (1993). Unit Root Tests in Panel Data: New Results, University of California, San Diego, Discussion Paper No: 93-56.

22. Leys, C. (1970). "What is the Problem About Corruption?”, In A. J. Heidenheimer (ed.), Political Corruption: Readings in Comparative Analysis, pp. 31-37. New York: Holt Reinehart.

23. Jain, K. A. (2001). Corruption: A Review, Journal of Economic Surveys, 15(1), 71-121.

24. Lui, F. (1985), “An Equilibrium Queuing Model of Corruption”, Journal of Political Economy, 93, 760-81.

25. Maddala, G.S., and Wu, S., (1999). A Comparative Study of Unit Root Tests with Panel Data and a New Simple Test, Oxford Bulletin of Economics and Statistics, Special Issue, 61:631-652. 
26. Mauro, P. (1995), Corruption and Growth, Quarterly Journal of Economics, 110(3), 681-712.

27. Mauro, P. (1998), "Corruption: Causes, Consequences and Agenda for Further Research", Finance \& Development, 11-14.

28. McCoskey, S., and Kao, C., (1998). A Residual-based Test for the Null of Cointegration in Panel Data, Econometric Reviews, 17:57-84.

29. Pedroni, P., (1995). Panel Cointegration, Asymptotic and Finite Sample Properties of Pooled Time Series Tests with an Application to the PPP Hypothesis, Indiana University.

30. _ (1997). Panel Cointegration, Asymptotic and Finite Sample Properties of Pooled Time Series Tests with an Application to the PPP Hypothesis, New Results, Indiana University.

31. Pelligrini, L ve Gerlah, R. (2008), Causes of Corruption: A Survey of Cross-Country Analyses and Extended Results, Economics of Governance, 9, 245-263.

32. Phillips, P. C. B., and Moon, H. R. (1999). Linear Regression Limit Theory for Nonstationary Panel Data, Econometrica, 67:1057-1111.

33. Quah, D. (1994). Exploiting Cross-Section Variation for Unit Root Inference in Dynamic Data, Economics Letters, 44:9-19.

34. Rijckeghem, V.C. and Weder, B. (2001). "Bureaucratic Corruption and the Rate of Temptation: Do wages in the Civil Service Affect Corruption, and by How Much?" Journal of Development Economics, 65, 307331.

35. Shleifer, A., Vishny, R.W. (1993). Corruption. The Quarterly Journal of Economics, 108, 519-617.

36. Tosun, M., U. (2003). Yolsuzluğun Nedenleri Üzerine Ampirik Bir Çalışma (An Empirical Study on the Causes of Corruption), Akdeniz I.I. ..B.F. Dergisi (5), 125-146. ss.

37. Transparency International (2010). http://www.transparency.org/ (reached: 24/09/2010).

38. Zakari, M. (2009). Openness and Corruption: A Time-Series Analysis, Zagreb International Review of Economics \& Business, 12(2),1-14. 